\title{
Comparing the performance of high-resolution global precipitation products across topographic and climatic gradients of Central Asia
}

Mayra Daniela Peña Guerrero ${ }^{1,2,3,4}$, Atabek Umirbekov ${ }^{1,2,3}$, Larisa Tarasova ${ }^{4}$, and Daniel Müller ${ }^{1,2,5}$

${ }^{1}$ Leibniz Institute of Agricultural Development in Transition Economies (IAMO)

${ }^{2}$ Geography Department, Humboldt-Universität zu Berlin

${ }^{3}$ Tashkent Institute of Irrigation and Agricultural Mechanization Engineers

${ }^{4}$ Department of Catchment Hydrology, Helmholtz Centre for Environmental Research, Halle (Saale)

${ }^{5}$ Integrative Research Institute on Transformations of Human-Environment System (IRI THESys), Humboldt-Universität zu Berlin

November 2, 2021

\section{Hosted file}

Pena-Guerrero_etal_submitted_manuscript_102021.pdf available at https://authorea.com/ users/442208/articles/543976-comparing-the-performance-of-high-resolution-globalprecipitation-products-across-topographic-and-climatic-gradients-of-central-asia 